\title{
As imagens simbólicas sobre o pranto feminino
}

\author{
The symbolic images about women lamentation
}

\section{Eunice Simões Lins Gomes, Leyla Thays Brito da Silva*}

Universidade Federal da Paraíba (UFPB), João Pessoa, PB, Brasil

\section{Resumo}

Nosso artigo analisa as imagens simbólicas sobre o pranto feminino, tendo como recorte analítico o episódio do evangelho apócrifo de Pedro, em que as mulheres dirigem-se ao túmulo de Jesus para realizar as honrarias fúnebres ao mestre. Trata-se de uma pesquisa descritiva e bibliográfica, com abordagem qualitativa. A concepção de pranto foi delineada sob a perspectiva mitológica e fundamentada com a teoria do imaginário, tendo como instrumento de análise a "Hermenêutica Simbólica de Gilbert Durand e a Mitohermenêutica de Ferreira-Santos". Consideramos que, em seu simbolismo de morte, o pranto dessas mulheres que choraram compulsivamente, ao ponto de se ouvir uma voz "Mulher por que choras?", apresenta a função de trazer à consciência da comunidade o término da vida, uma vez que o espetáculo da dor emocional descrito com o bater no peito e o puxar de cabelos, enfim, o lamento fúnebre, revela a angústia diante do tempo e da morte.

Palavras-chave: Pranto. Hermenêutica Simbólica. Imaginário. 


\section{Abstract}

This paper aims to reveal the essence of the narrative and symbolic images about women lamentation, with the analytical approach of the episode from the apocryphal Gospel of Peter, in which women run to the tomb of Jesus to perform funeral honors for the master. This is a descriptive and bibliographical research, with a qualitative approach. The concept of lamentation was outlined in the mythological perspective and based on the theory of the imaginary, having as instrument of analysis the "Symbolic Hermeneutics of Gilbert Durand and the Mythological Hermeneutics of FerreiraSantos". We consider that in its symbolism of death, the lamentation of these women who wept uncontrollably, to the point of hearing a voice, "Woman, why are you crying?" presents the function of bringing to the community conscience the ending of life, since the spectacle of emotional pain described with the chest beating and hair pulling, in short, the funeral lament, reveals the anguish in the face of time and death.

Keywords: Lamentation. Symbolic Hermeneutics. Imagination.

\section{Introdução}

Após toda a jornada de sofrimento até o calvário, a crucificação e morte de Jesus, onde tudo parecia ser o fim, com a segurança do sepulcro fortalecida pela guarda imperial selando a pedra para que o corpo de Jesus não desaparecesse, preciosas mulheres, que não puderam cuidar do corpo de Jesus após a sua morte, como era do costume judaico ungir o corpo do morto, saíram no fim do sábado, quando já despontava o primeiro dia da semana, levando consigo aromas e tendo como propósito ungir o corpo do seu mestre. No entanto, grande foi a surpresa, encontraram o túmulo vazio. Atônitas começaram a procurar o seu mestre, a chorar - um pranto desesperador tomou conta delas, onde o puseram? Onde se encontra o mestre? Ecoa então uma voz no meio da angústia, em forma de pergunta: "Mulher, por que choras?" (Jo 20,15).

A partir da leitura efetuada no evangelho apócrifo de Pedro, delimitamos nosso recorte para desenvolver nossa análise, selecionando especificamente a passagem "As mulheres e o sepulcro". Em seguida 
construímos o objetivo deste texto, que consiste em desenvolver uma análise mítica e simbólica deste relato, que se trata de uma passagem rica de imagens com suas simbologias míticas. Este pranto das mulheres, o desespero que elas sentiram ao chegarem ao túmulo de Jesus após a sua morte, levando consigo aromas, com o propósito de ungir o corpo, e não o encontrarem serão alvos de nossa análise no decorrer do texto; por isso, convidamos o leitor para adentar neste espaço mítico e simbólico.

Contextualizando o livro selecionado para estudo, os fragmentos do evangelho apócrifo de Pedro (tò legómenon katà Pétron euaggélion), sem contar a parte introdutória e as considerações finais do livro, foram descobertos no inverno de 1886-7, em um velho pergaminho do século VIII-IX, na sepultura de um monge cristão de Akhmîm (no Alto Egito). O texto já estava esquecido pelos modernos, embora os escritores antigos dele tivessem ciência, como Eusébio, Orígenes e Gelasiano.

Estes escritos registram o momento final de Jesus, sua condenação e escárnio, a guarda do sepulcro, a ressurreição de Jesus e as mulheres e o sepulcro. Delimitamos como já mencionamos as mulheres e o sepulcro para serem analisados de forma descritiva e simbólica, alicerçados na abordagem qualitativa, com a fundamentação da teoria geral do imaginário, utilizando como método de análise a hermenêutica simbólica.

Consideramos que o imaginário não é um simples conjunto de imagens que vagueia livremente na memória e na imaginação. Ele é uma rede de imagens na qual o sentido é dado na relação entre elas; as imagens organizam-se de acordo com certa lógica, certa estruturação, de modo que a configuração mítica do nosso imaginário depende da forma como arrumamos nele nossas fantasias (GOMES-DA-SILVA; GOMES, 2010, p. 100). É dessa configuração que decorre o nosso poder de melhorar o mundo, recriando-o, cotidianamente, pois o imaginário é o denominador fundamental de todas as criações do pensamento humano (DURAND, 1997).

No momento da análise das imagens selecionadas como recorte do estudo, esclarecemos que estaremos efetuando um olhar atento, minucioso e cuidadoso, principalmente diante das possíveis armadilhas que a interpretação de um texto nos coloca, pois, segundo Eco (1993, p. 41) 
"um texto é um universo indefinidamente aberto que o interprete pode descobrir interligações infinitas [...]”.

Portanto, desenvolveremos a análise das imagens pregnantes que selecionamos de forma compreensiva - uma vez que não estaremos olhando o texto (evangelho apócrifo de Pedro) como uma estrutura fixa, mas na dinâmica de texto com o leitor: "um texto" que "olha-nos" é mais que interesse específico das pesquisadoras; é sim um cruzamento de olhares segundo Durand (1982, p. 66).

É neste cruzamento de olhares, que o imaginar configura a premissa primeira para o conhecimento, portanto, estaremos conciliando em nossa análise a relação entre razão e imaginação, e acatando que uma não pode prescindir da outra.

Com isso chegamos ao propósito central de nossa análise. A partir da imaginação simbólica construiremos a reflexão mítica e simbólica em dois momentos: Começaremos com uma exposição sobre as mulheres e o sepulcro; e depois dedicaremos uma parte para refletir sobre a imaginação mítica do pranto. Convidamos o leitor para uma reflexão sobre as motivações míticas e ritualísticas que emolduram o desconsolo e a necessidade de pranto das mulheres perante a perda do mestre querido.

\section{As mulheres e o sepulcro}

Etimologicamente o termo hermenêutica deriva do verbo grego hermeneúo, oriundo de Hermes, que na Grécia antiga era um personagem mítico, douto do saber e que possuía a arte de interpretar. No entanto, é possível considerar a hermenêutica nos seus primeiros passos com a função de desvendar o sentido dos textos bíblicos, por ter como seu objeto a interpretação. Atualmente a hermenêutica é considerada como uma teoria da interpretação e da compreensão do sentido das palavras, seja de textos sagrados ou de uma interpretação de textos clássicos, jurídicos e históricos.

No entanto, estaremos em nossa análise apoiados na hermenêutica simbólica de Durand, que é um método próprio ao estudo do imaginário, válido para qualquer mensagem que emana do homem e sustentado na mitohermenêutica, que, segundo Ferreira-Santos (2005 apud PAREDES, 
2011), "contribui com o processo de compreensão das obras da cultura, a partir dos traços míticos e arquetipais captados por meio dos arranjos narrativos das suas imagens e símbolos, na busca dinâmica de sentidos para a existência". Entendemos que esta mitohermenêutica distancia-se de qualquer sistematização cartesiana, pois segundo o autor, ela articula o rigor necessário à reflexão e investigação ao vigor do mundo vivido, complexo, contraditório, híbrido (FERREIRA-SANTOS, 2005 apud PAREDES, 2011).

Para Ferreira-Santos (2005), como citado por Paredes (2011), a mitohermenêutica inscreve-se como "hermenêutica simbólica de cunho antropológico, que se apresenta como estilo filosófico, no sentido de manter uma atitude de inquietação e questionamento e como método de investigação, no sentido de estabelecer procedimentos sistemáticos de pesquisa" científica.

Nessa abordagem analisamos a maneira como se organizam as representações da narrativa mítica do pranto e elegemos algumas passagens, retiradas do recorte do evangelho apócrifo de Pedro e dos evangelhos sinóticos, que acreditamos serem expressivas para a compreensão da análise, pois de acordo com Ferreira-Santos (2004, p. 14):

se podemos compreender, inicialmente, um texto como um tecido tramado de fios e urdiduras com palavras que desta forma, dão sentido e significado a uma imagem ou ideia estampados sobre a trama, [...] é no delírio poético da palavra que se rompe as regras para criar e ser fiel ao movimento da imagem, sendo possível compreender a imagem ou a ideia veiculada pelo texto, não explicando-a, e sim interpretando.

Para tanto, estaremos no primeiro momento desvelando o fio da narrativa a partir das mulheres e em seguida sobre o sepulcro.

\section{0 imaginário das mulheres}

Encontramos no evangelho sinóptico de Marcos $(16,1)$ o registro de três mulheres que procuravam o corpo do mestre: Maria Madalena, Maria mãe de Thiago e Salomé. Estas mulheres conheciam de perto o mestre, diversas vezes o acompanharam em seu ministério desenvolvendo várias 
atividades com ele e em outras foram assistidas por ele, principalmente Maria Madalena.

No evangelho de Lucas $(23,56)$ encontramos a passagem da saída das mulheres para preparar aromas e bálsamos. Destaque-se esse momento eminentemente feminino, em que elas foram comprar as especiarias, mirra e óleos para preparar os aromas, os quais exalavam um perfume sem igual. Foram cuidadosas, zelosas, característica bem peculiar do sexo feminino. Possivelmente o fizeram como uma expressão de gratidão diante das virtudes que o mestre favoreceu para todos aqueles que o procuraram, curando-os, libertando-os e transformando-os, inclusive a elas próprias, cuja ação de cuidar do corpo moído e dilacerado do mestre significava cuidar do próprio mestre, fazer o que não lhe fora permitido na jornada de sua dor.

Certa vez Jesus foi assistido por algumas mulheres, tal como no caso de Maria e Marta irmãs de Lázaro, que escutavam as suas palavras. Marta escutava mais agitada, não parava os seus afazeres - era uma forma que encontrava de servir ao mestre; Maria, porém, ficava "assentada aos pés do Senhor a ouvir-lhe os ensinamentos”, (Lc 10,38), e Jesus responde a Marta quando esta o questiona sobre Maria, que em vez de ir fazer as atividades ficou assentada: "Maria escolheu a boa parte" (Lc 10,42). Era um momento precioso, sentar, parar, aquietar-se e ouvir.

Em outro momento novamente Maria irmã de Lázaro surpreende com sua atitude. Ela, "tomando uma libra de bálsamo de nardo puro, mui precioso, ungiu os pés de Jesus e os enxugou com os seus cabelos, e encheu-se a casa com o perfume do bálsamo" (Jo 12,3). Ela de forma antecipada exerceu o ato que só acontecia no momento de embalsamarem o corpo. É possível perceber, na atitude desta mulher em ir ao encontro do mestre e ungir os seus pés, uma força destemida, um enfrentamento, próprio do regime diurno, bastante heroico.

No caso do evangelho apócrifo de Pedro, foco de nossa análise, a grande perspicácia destas mulheres foi esperar a hora certa para agir, o tempo favorável para irem ao sepulcro em busca do corpo para ungir antes de embalsamarem. Saíram; "na alta madrugada foram ao tumulo levando os aromas que haviam preparado" conforme registra o evangelho de Mateus $(24,1 \mathrm{a})$. O propósito era aspergir os aromas que haviam preparado sobre o corpo do mestre. O perfume exalado pelo aroma da mirra 
e do óleo sobre o corpo do mestre possivelmente simbolizaria assim a sua memória e evocaria a ideia de purificação, e pensariam no seu corpo ungindo, um ato que remete ao regime noturno, cheio de seu eufemismo.

Elas temiam ser vistas pelos judeus e diziam: "se, no dia em que foi crucificado, não podemos chorar e lamentar-nos batendo no peito, façamo-lo pelo menos agora no seu túmulo. Quem, no entanto, nos há de revolver a pedra colocada na entrada do sepulcro, a fim de que possamos entrar, sentar-nos em volta e cumprir o que lhe é devido: A pedra é grande e tememos que alguém nos veja. Se não o pudermos fazer, deponhamos, pelo menos, na porta o que trouxemos em sua memória. Choraremos e nos lamentaremos batendo-nos o peito, até a hora de voltarmos para casa" (XII, v. 51-54).

Embora o contexto histórico da época revele que as mulheres não ocupavam um lugar de destaque, uma das tarefas que elas deveriam fazer era a unção do corpo do morto, um rito que fazia parte do ritual judaico empregado para consagração desse corpo. Como também desconfiamos pelo fato de não terem ungido antes de o colocarem no túmulo, pois não fora permitido, estas mulheres não aquietariam o coração enquanto não cuidassem do corpo do seu mestre, por isso insistiram em ir e assim o fazer. Elas foram determinadas, destemidas e enfrentaram o medo, um ato bem heroico, próprio do enfrentamento diurniano.

Ir ao sepulcro, ao lugar da dor, do encontro da angústia diante da morte, não era uma tarefa fácil, sem falar do risco que elas corriam — poderiam ser presas. No entanto, mesmo confrontadas com todo o temor e tremor, elas foram e enfrentaram a dor, o medo. "Ao amanhecer do dia, do sabat, as mulheres foram em busca do corpo do mestre no sepulcro" (Mt 28,1). Este gesto remete à dominante postural, à tecnologia das armas, ao herói, à verticalidade, em marcha, em pé, caminhando apressadas no meio da escuridão, bem como remete aos rituais de purificação, ou seja, ao regime diurno.

Outro fato que podemos ressaltar diz respeito ao próprio momento da crucificação, em que muitos se esconderam, fugiram, negaram seguir Jesus. Era um momento de grande confusão que assustava a todos, um verdadeiro formigamento, agitação por todos os lados. Os soldados estavam tomados de medo, horror e ordenanças para cumprir, o que remete aos símbolos teriomorfos, a uma boca aberta cheia de dentes para 
devorar, os gritos fortes dos soldados, a ordem de marcha, toda a multidão estava envolvida por um redemoinho de emoções: por um lado, amor; por outro, muito ódio; o desejo de socorrer, acolher, retirá-lo da dor, mas também desprezo, muito pranto e muita ironia, zombarias. A cena remete à angústia temporal; a agitação, que predominava na cena, a um caos, ao simbolismo da angústia diante da morte, à crueldade, à boca aberta com gritos de ordem para Gólgota, para o destino final, a morte.

O animal é, assim, de fato, o que se agita, o que foge e que não podemos apanhar, mas, é também o que devora, o que rói. É pois, a boca aberta que passa a simbolizar toda a animalidade, que se torna o arquétipo devorador (DURAND, 1989, p. 61).

O percurso de Jesus continuava de forma solitária, ninguém se aproximava para ajudar, para retirá-lo daquela situação. Os que de fato se aproximavam de Jesus o empurravam, zombavam e, como não havia espaço para as mulheres, elas acompanhavam de longe todo o sofrimento, sem poder enfrentar aquela multidão agitada. O que se encontra em alguns registros do texto é que José de Arimateia, por ser amigo de Pilatos e do mestre, pediu o corpo de Jesus para ser sepultado. Pilatos então encaminha o pedido para Herodes, que assim o permite, conforme o evangelho apócrifo de Pedro (II, v. 3).

Era meio-dia quando as trevas cobriram toda a Judeia (V, v. 15). A imagem deste momento era de grande escuridão, e "chegada a hora sexta, houve trevas sobre toda a terra até a hora nona" conforme registra o evangelho de Marcos (15,33), até o momento em que Jesus expirou, e deram o seu corpo a José de Arimateia. Este, envolvendo o mestre em um lençol, depositou-o em seu próprio sepulcro novo, um que ninguém tinha usado, tal como havia solicitado a Pilatos, conforme registra o evangelho de Marcos (15,43): "envolveu o corpo em um lençol que comprara e o depositou em um túmulo que nunca tinha sido aberto numa rocha”.

Este momento de dor e angústia foi tomado por todos. Desconfiamos que os discípulos se esconderam, tal como todos aqueles que seguiam o mestre - inclusive algumas mulheres. Outros ficaram observando de longe, até porque poderiam também ser presos ou crucificados. Todos estavam tomados de grande horror. 


\section{0 imaginário do sepulcro}

O sepulcro, lugar que afirma a perenidade da vida, lugar de acolhimento e repouso de tanta dor, humilhação e afronta, segundo Jung "é o lugar da metamorfose do corpo em espírito" (CHEVALIER; GHEERBRANT, 2002, p. 915). Remete ao regime noturno do imaginário, a descida, ao redobramento, trevas. O credo apostólico diz que "foi crucificado, morto e sepultado; desceu ao Hades (que remete a trevas, inferno, escuridão)". Vejamos o que Durand nos diz:

Introduz uma doce necrofilia que traduz consigo uma valorização positiva do luto e do túmulo. [...] As fantasias da descida noturna implicam, naturalmente, a imagística colorida das tintas. E o esquema do engolimento da regressão noturna projeta, de algum modo, a grande imagem materna pelo meio-termo da substância, da matéria primordial, quer marinha, quer telúrica (1989, p. 156).

Essas imagens remetem ao simbolismo da intimidade, tão presente no regime noturno, tal como a valorização da própria morte e sepulcro, o lugar do último repouso. Nesta passagem, Jesus desce ao inferno para pegar as chaves da vida, um momento de luta, de enfrentamento, ou seja, uma descida com uma ascensão, pois em seguida ele "ressurgiu dos mortos ao terceiro dia; subiu ao céu" - como se pode notar, há símbolos de ascensão. "No seio da própria noite, o espírito procura a luz e a queda se eufemiza em descida e o abismo minimiza-se em taça. [...] desce-se para subir no tempo e reencontrar as quietudes pré-natais. O abismo transmutado em cavidade, se torna uma finalidade [...]" (DURAND, 1989, p. 138-141).

Embora o túmulo tenha sido selado com uma pedra e vigiado por vários soldados durante três dias, nada impediu a ressurreição.

Mas durante a noite que precedeu o dia do Senhor, enquanto os soldados montavam guarda, por turno, dois a dois, ressoou no céu uma voz forte e viram-se abrir os céus e descer de lá dois homens, com grande esplendor, e aproximar-se do túmulo [...] os soldados disseram, era verdadeiramente o filho de Deus conforme evangelho apócrifo de Pedro (XIX e X, 35-42). 
Percebemos como as imagens aglutinam-se, no imaginário, em torno de núcleos organizadores da simbolização, que são polarizados. Em cada núcleo, ou polo, há uma força homogeneizante, ordenadora de sentido, que organiza semanticamente as imagens, configurando-as, miticamente, em três estruturas, que gravitam em torno de três esquemas matriciais básicos: heroico (separar), místico (incluir) e sintético (dramatizar). O primeiro põe em ação imagens e temas de luta (do herói contra o monstro, do Bem contra o Mal); o segundo, imagens assimiladoras, e o terceiro põe em conjunto imagens divergentes, integrando-as numa ação.

Nessa perspectiva, o imaginário não é um simples conjunto de imagens que vagueiam livremente na memória e na imaginação. Ele é uma rede de imagens na qual o sentido é dado na relação entre elas; as imagens organizam-se de acordo com uma certa lógica, uma certa estruturação, de modo que a configuração mítica do nosso imaginário depende da forma como arrumamos nele nossas fantasias. É dessa configuração que decorre o nosso poder de melhorar o mundo, recriando-o, cotidianamente, pois o imaginário é o denominador fundamental de todas as criações do pensamento humano (DURAND, 1997).

Ao longo de sua obra, Durand mostra que a imaginação é reação da natureza contra a representação da inevitabilidade da morte. O desejo fundamental buscado pela imaginação humana é reduzir essa angústia existencial face à consciência do Tempo e da Morte. Entende este autor que esta função (que em última instância é eufemização) não é simplesmente ópio negativo, máscara que a consciência veste diante da figura horrível da morte, mas, ao contrário, dinamismo prospectivo que, através do imaginário, tenta melhorar a situação do homem no mundo (DURAND, 1988). Portanto, é para fugir da representação da morte que a imaginação cria o mundo.

\section{0 pranto feminino: simbologias do lamento fúnebre}

A manifestação corporal do choro consiste em uma imagem somática que consubstancia narrativas míticas. $\mathrm{O}$ mito, em sendo uma 
narração, não deixa de situar-se no plano da racionalidade, na medida em que a urdidura do enredo mítico se dá pela concatenação e organização de imagens e símbolos. Contudo, a poiesis mítica, além de constituir-se na dimensão do logos, também se formula das pulsões de nossa corporeidade, naquelas experiências mais imediatas do corpo, como a fome, a menstruação, a ereção e o choro. Desse modo, como propõe Keleman em diálogo com Campbell, em Mito e Corpo (2001), o mito constitui e comunica a nossa "humanidade somática". Nessa injunção logos e soma, o construto mítico dá voz e clarifica a nossa realidade interna, que parece se comportar de modo resistente a uma apreensão racional.

Quanto ao brotar das lágrimas, inscreve-se na imaginação sob uma diversidade de implicações simbólicas. Se por um lado as lágrimas associadas ao grito do recém-nascido são indicativas de vida, por outro lado, o pranto que umedece as faces também é ícone de morte, ante a experiência do luto. Vejamos: "Maria permanecia junto à entrada do túmulo chorando" (Jo 20,11). Portanto, podemos considerar que a pulsão do choro alicerça imagens significativas de vida e morte, isto é, de Eros e Tânatos. Não por acaso, é recorrente em várias narrativas fantásticas, em contos de fadas, por exemplo, a presença da lágrima que ressuscita. O pranto promovido pelo luto, após derramar-se sobre o corpo sem vida, converte-se em energia ressuscitadora. Portanto, em seu caráter simbólico, o pranto apresenta essa ambivalência de significações na qual vida e morte estão imbricadas.

$\mathrm{Na}$ linha simbólica nictomórfica do regime diurno, encontra-se a água que foi o primeiro espelho do homem. A água é tenebrosa, é substância simbólica da morte, porque nasce na fonte e não volta jamais a ela, sendo, também, símbolo do tempo. A água leva ao símbolo do dragão, forma meio serpente, meio pássaro, grande devorador, portanto, ao mesmo tempo o símbolo teriomórfico e aquático, pois é uma combinação dos arquétipos da fera, da noite e da água (DURAND, 1989). A água noturna apresenta-se, também, sob outro aspecto: as lágrimas ou, ainda, as ondas. Estas e a água/espelho convergem para a cabeleira e o coquetismo e inclinam-se para uma feminização, chegando à água feminina e nefasta por excelência: o sangue menstrual.

No que diz respeito a prantear os mortos, é constante a presença do choro feminino na iconografia fúnebre de determinadas culturas. $\mathrm{Na}$ 
tradição da antiguidade grega, o lamento fúnebre era parte de uma das etapas do ritual. Podemos perceber este contexto conforme o relato do evangelho apócrifo de Pedro, quando as mulheres saíram em busca do corpo do mestre para ungir, como preparam os aromas para perfumar, suavizar o corpo do mestre mutilado através do gesto simbólico e marcante.

Antes de tudo, o corpo era limpo, perfumado e amortalhado pelas mulheres, para depois ser exposto aos parentes no momento da próthesis (exposição). A partir de então, cabia também às mulheres o prantear, que era indispensável. A figura da carpideira podia ser comprada ou obrigada a exercer tal função. O choro ritual era acompanhado por gritos estridentes, pelo puxar dos cabelos, bater no peito e arranhar as faces (BURKERT, 1993, p. 374). Conforme registra o evangelho apócrifo de Pedro, "não pudemos chorar e lamentar-nos batendo no peito", o bater no peito se revelava a expressão da dor da perda, do sentimento de culpa, "onde o puseram", bem como do desejo de se redimir ungindo o corpo do mestre.

Sendo a ação que demarcava a primeira exposição do corpo, o choro feminino tinha uma função social de anúncio da morte e expressão do sentimento de dor e luto. Em quase toda literatura greco-romana, o espetáculo do pranto feminino é núcleo das cenas de morte. Na tragédia grega As Troianas, do dramaturgo Eurípides (séc. V a.C.), as mulheres de Troia, após a destruição de sua cidade na guerra entre gregos e troianos, extravasam, ao longo de toda peça, os seus lamentos pela perda da pátria, dos maridos, dos filhos e da dignidade própria, ao tornarem-se cativas do inimigo. O pranto coletivo das troianas, liderado pela rainha Hécuba, consiste no extravasar das emoções ante a dor do luto. A título de exemplo, considerem-se as indicações cênicas do choro de Hécuba, quando descobre que se tornará serva de um dos seus principais inimigos, o herói grego Odisseu, o idealizador do cavalo de Troia. Num doloroso monólogo, a rainha vencida traz aos olhos do público o seu prantear trágico: "Golpeia esta cabeça maltratada! Fere com as unhas o teu rosto triste!" (EURÍPIDES, 2003, v. 338-339).

Essa cena, visualmente, aproxima-se do gestual das carpideiras na próthesis do morto. Do mesmo modo, a rainha Hécuba lamenta a morte do neto Astiânax, que era o único descendente masculino ainda vivo do reino de Troia, por isso a última esperança de que a cidade fosse reerguida, em 
sua estrutura patrilinear. Ante essa terrível perda, o espetáculo do prantear feminino é o último recurso perante a morte:

Minha criança! Filho de meu filho!

Meu pobre neto! Violência iníqua!

Tiraram-te à vida, à tua mãe, a mim!

Que está por vir? Que posso eu agora

Fazer por ti, vencida pela sorte?

Oferecer-te os golpes com que firo

o meu rosto e meu mortificado peito?

É pouco, eu sei, e é tudo quanto posso (EURÍPIDES, 2003, v. 1114-1118).

No entanto, para além da dor trágica veiculada e exacerbada pelo pranto ritualístico da morte com as carpideiras, as lágrimas, ao que tudo indica, são representadas miticamente e ritualisticamente como um elemento procriativo, cuja força genésica revela seu poder no cosmos natural. Diante disso, a relação da mulher com o pranto, como se pode ver na instituição ritualística das carpideiras para o transbordamento da dor ante o desalento, pode ainda ser ponderada a partir da relação dos ritos fúnebres com os ritos de fecundidade.

Conforme aponta Eliade (2002b) em Tratado de História das Religiões, os destinos fúnebres e agrários pertencem ao mesmo escopo existencial, que consiste no momento pré-germinal da vida. Portanto, "semelhante às sementes enterradas na matriz telúrica, os mortos esperam o seu regresso à vida sob uma nova forma." (p. 283). Os mortos comparam-se às sementes, uma vez que, ao habitarem o interior da terra, possuem os segredos progênitos das zonas misteriosas do seio da Grande-Mãe, por isso exercem uma função de intercessores para o sucesso agrário.

Numa compreensão durandiana, como a água está submetida ao influxo da Lua e como é germinativa, está também ligada ao símbolo agrário que é Lua. No entanto, a maioria das mitologias confunde água e Lua. O isomorfismo da Lua e das águas é uma feminização, pois a Lua se liga à menstruação, havendo muitas lendas que tratam dessa ligação. A este isomorfismo se atribui o símbolo da imagem da Mãe Terrível, a gigante que fortifica a interdição sexual e leva à misoginia, aos perigos da sexualidade. 
Neste esquema simbólico, coloca-se a aranha, que é símbolo da Mãe que conseguiu aprisionar o filho em suas malhas. O fio passa, portanto, a representar o destino humano e a ele estão ligados as rocas, as fiandeiras, o labirinto, os laços que constituem, todos, simbolismos negativos, pois ligam-se ao poder mágico e nefasto da aranha, do polvo e, também, da mulher fatal e mágica.

Nesse sentido, é possível fazer uma associação dessa dualidade morte-fecundação com a figura feminina, que é a principal agenciadora da fertilidade nos ritos agrários. Essa solidariedade entre a mulher e a agricultura, já amplamente pesquisada pela antropologia e arqueologia, pode ser uma das causas da institucionalização do pranto fúnebre feminino.

Se cabe à mulher oficialmente chorar os mortos, é porque a força fecundante que ela exerce sobre as sementes também pode ser exercida sobre os não viventes, desejosos de energia vital. Se a água é o liquido seminal por excelência, "receptáculo de todos os germes" (ELIADE, 2002b), não é à toa que a lágrima, como já apontamos, pode converter-se em elemento ressuscitador. Assim a lágrima feminina, água que brota dos olhos, nas honrarias fúnebres, assegura o renascimento post-mortem.

Em termos míticos, a imagem do choro fúnebre como força fecundante é recorrente em diversas mitologias. Na mitologia egípcia, as lágrimas do deus Aton, por ter perdido os filhos, fecundam a terra, gerando, então, a humanidade. Na mitologia indígena, são as lágrimas da mãe da índia Mani, que chorando sobre o túmulo da filha, possibilitam o surgimento da planta da mandioca. Na mitologia grega, com o poeta Bíon de Esmirna (séc. IV a.C), as lágrimas da deusa Afrodite, pelo amado morto Adônis, geram as belas flores anêmonas.

Veja-se que as imagens míticas que emolduram o simbolismo das lágrimas apontam para uma estreita relação entre o caráter vital e o caráter trágico do pranto. Considerando a percepção do poeta latino Ovídio em seu conjunto de poemas chamados Metamorfoses, no qual várias narrativas míticas são compiladas sob o signo da morte que se metamorfoseia em vida, a lágrima é uma agente transmutador, cuja ação converte o pranto em agente vital para o nascimento de um novo elemento natural, seja uma flor, uma ave ou o próprio homem. 
Portanto, podemos considerar que o símbolo do pranto se imprime de uma dualidade em que Eros e Tânatos são a um só tempo atuantes. Destarte, cabe agora ponderar sobre o prantear das mulheres em busca do corpo de Cristo nessa perspectiva simbólica em que podemos inscrever o lamento fúnebre, considerando nossas reflexões míticas e ritualísticas sobre o pranto.

A ida das três mulheres ao sepulcro corresponde ao desejo de oferendar as honrarias fúnebres, os aromas, a unção ao mestre morto e tão amado por elas, com todo o preparo que caberá ser feito pelas mulheres nesse ritual. Assim descreve o evangelista Pedro acerca desse episódio:

Ao amanhecer do dia do senhor, Maria Madalena, discípula do Senhor, que, por medo dos Judeus ardentes de cólera, não havia feito na sepultura do senhor tudo quanto as mulheres costumavam a fazer pelos mortos que lhes eram caros, tomou consigo as amigas e dirigiu-se ao túmulo onde tinha sido posto. Elas temiam ser vistas pelos judeus e diziam: "Se no dia em que foi crucificado, não pudemos chorar e lamentar-nos batendo no peito, façamo-lo pelo menos agora em seu túmulo" (XII, 50-52).

A partir desse trecho podemos reconhecer algumas referências significativas acerca do papel da mulher nos ritos fúnebres. Primeiramente alude-se aos costumes femininos em relação às honrarias fúnebres no verso "tudo quanto as mulheres costumavam fazer pelos mortos." Também se evidencia o gestual desesperador com o qual as mulheres devem lamentar o morto, "batendo no peito". Nesses trechos, pode-se reconhecer a semelhança do prantear desejado por elas com as imagens descritas nos ritos fúnebres gregos e no mito das troianas.

No entanto, diferentemente do espetáculo das carpideiras gregas, as fiéis do Cristo pretendiam realizar seu lamento num momento íntimo, distante do público, já que lhes fora proibido, pelos judeus, honrar o corpo do mestre. Porém, ao entrarem no túmulo e receberem do anjo a notícia de que o Cristo havia ressuscitado, o seu prantear se transforma em perplexidade: "onde o puseram?".

Em não havendo o corpo para ser chorado e lamentado, estamos diante do caso de autorressuscitação, que dispensa a lágrima revivificadora da mulher. Se o Cristo ressuscitara, a água seminal da lágrima feminina, 
acolhedora da força genésica que transmuta a morte em vida, não poderia exercer sua função revitalizadora sobre o morto, uma vez que este transcende a condição de mortalidade. Daí o episódio do prantear feminino sobre o corpo de Jesus estar ausente na narrativa do evangelista Pedro.

Se a condição de imortalidade do Cristo, na narrativa do evangelista, dispensa o pranto feminino, uma vez que detém o poder de ressuscitação, o desejo dos mortos por reviver, mesmo que pela metamorfose num elemento natural, é reiteradamente representado nos ritos e mitos, como temos apresentado ao longo do texto. Se culturalmente foi dado à mulher esse papel de prantear os mortos, talvez isso se justifique pela própria natureza dialética em que o feminino miticamente é delineado. Por um lado, considerando a corporeidade feminina, os ritos e mitos apresentam as mulheres como agentes da fecundidade agrária, em sua função maternal associada aos poderes da Grande-Mãe, da qual a vida germina.

Por outro lado, os mitos, sobretudo os de criação, trazem a mulher como pulsão de morte e queda. As primeiras mulheres míticas, como Eva e Pandora, a um só tempo, permitem a reprodução, mas uma reprodução ligada à queda e à morte de uma condição sublime anterior.

Portanto, acolhendo as pulsões de Eros e Tânatos em sua natureza mítica e ritualística, as mulheres que foram ao túmulo do mestre, bem como a mulher enquanto carpideira das almas, trazem a dualidade, a polaridade que Durand apresenta na sua teoria do imaginário, que confere ao pranto sua dupla natureza de vida e morte.

Em seu simbolismo de morte, as lágrimas das carpideiras, dessas mulheres que choraram compulsivamente, a ponto de se ouvir uma voz "Mulher por que choras?", temos a função de trazer à consciência da comunidade o término da vida, uma vez que o espetáculo da dor emocional, delineado corporalmente com o bater no peito e o puxar de cabelos, o desespero, a angústia diante do tempo e da morte, próprio das faces do tempo no trajeto antropológico, faz-se necessário para que se tome conhecimento da repercussão da morte sobre os que ficam. Apesar disso, no evangelho apócrifo de Pedro, o texto apresenta que a morte não foi o fim. Cristo se revela, ressuscitado, e a mulher que chorava amargamente, ao ouvir a sua voz, o reconhece, Rabôni, Mestre (Jo, 20,16). O pranto, que a princípio era de uma dor terrível, agora se transforma em pranto de 
alegria, ele está aqui, é o meu mestre, é a convergência simbólica sim, é o recomeço de uma nova jornada.

\section{Considerações finais}

Consideramos, apoiados em Durand, que é na trajetividade que a representação do objeto se deixa assimilar e modelar pelos imperativos pulsionais do sujeito e, reciprocamente, as representações subjetivas explicam-se pelas acomodações anteriores do sujeito ao meio objetivo.

Portanto, existe um processo dinâmico, de acordo com as imagens da narrativa mítica e simbólica que desenvolvemos no recorte do evangelho apócrifo de Pedro, principalmente no objeto de nossa análise, "as mulheres e o sepulcro", onde encontramos confrontados os dois regimes de imagens - o diurno e o noturno - um determinando o outro, ditando uma sintaxe e uma lógica que fundamentam a mentalidade dominante.

Ressaltamos que o regime diurno é o da antítese, os monstros hiperbolizados são combatidos por meio de símbolos antitéticos: as trevas são combatidas pela luz e a queda pela ascensão. O regime noturno é o da antífrase, está constantemente sob o signo da conversão e do eufemismo, invertendo radicalmente o sentido afetivo das imagens (DURAND, 1997).

Dessa forma, tanto no domínio mental individual, como no coletivo, só há verdadeira polaridade quando há tensão heterogênea entre sistemas de representação separadamente homogêneos. Estes dois regimes não podem ser entendidos como estruturas fixas, mas como linhas de força de coesão e jamais como tipologias psicológicas ou sociológicas, que agrupam de forma dialética as imagens simbólicas.

Mas em seu simbolismo genésico, o pranto das mulheres, ligado à condição somática feminina de geradora de vida, sinaliza para uma nova existência que recai sobre o morto-semente. Nesse sentido, sendo o pranto, como temos considerado, movido por Eros e Tânatos, os mitos e ritos nos permitem ponderar que o prantear feminino tem, em seu sentido simbólico, essa ambivalência de Morte e Vida que é matriz da organização cósmica, e o texto ora analisado inicia com a morte e termina com uma nova vida, a ressurreição; inicia com o pranto e termina com o gozo. 


\section{Referências}

APÓCRIFOS. OS PROSCRITOS DA BÍBLIA. Diversos tradutores. São Paulo: Mercúrio, 1992.

BIBLIA DE JERUSALEM. São Paulo: Edições Paulinas, 1981.

BIBLIA SAGRADA NOVA VERSÃO INTERNACIONAL. São Paulo: Sociedade Bíblica do Brasil, 2000.

BRANDÃO, J. S. Mitologia Grega. Petrópolis: Vozes, 2009. v. I

BURKERT, W. Religião Grega na época clássica e arcaica. Lisboa: Fund. Calouste Gulbenkian, 1993.

CHEVAliER, J.; GHEERBRANT, A. Dicionário de símbolos. Mitos, sonhos, costumes, gestos, formas, figuras, cores, números. 17. ed. Rio de Janeiro: Jose Olympio Editora, 2002.

DURAND, G. A imaginação simbólica. Trad. Eliane Fitipaldi Pereira. São Paulo: Cultrix, 1988.

DURAND, G. As estruturas antropológicas do imaginário: introdução à arquetipologia geral. Lisboa: Presença, 1989.

DURAND, G. As estruturas antropológicas do imaginário. 2. ed. São Paulo: Martins Fontes, 2001.

DURAND, G. L'Imaginaire: essai sur les sciences et la philosophie de l'image. Trad. José Carlos de Paula Carvalho. Rev. Técnica: Marcos Ferreira Santos. Paris: Hatier, 1994.

DURAND, G. Mito, símbolo e mitodologia. Lisboa: Editorial Presença, 1982.

DURAND, G. As estruturas antropológicas do imaginário. (Trad. de Hélder Godinho). Lisboa: Presença, 1997/2007.

ECO, U. Interprretação e história. Lisboa: Presença, 1993.

ELIADE, M. Imagens e símbolos: Ensaio sobre o simbolismo mágico-religioso. Trad. Sonis Cristina Tamer. São Paulo: Martins Fontes, 2002a. 
ELIADE, M. Tratado de história das religiões. São Paulo: Martins Fontes, 2002b. EURÍPIDES. Medéia, Hipólito, As Troianas. Trad. Mario da G. Kury. Rio de Janeiro: Jorge Zahar, 2003.

FERREIRA-SANTOS, M. A sacralidade do texto em culturas orais. Diálogo, Revista de Ensino Religioso, São Paulo, v. IX, n. 35, p. 14-18, ago. 2004.

FERREIRA-SANTOS, M.; GOMES, E. S. L. (Orgs.). Educação e religiosidade: imaginários da diferença. João Pessoa: Ed. UFPB, 2010.

GOMES-DA-SILVA, P. N.; GOMES, E. S. L. Malhação: corpo juvenil e imaginário pós-moderno. João Pessoa: Ed. UFPB, 2010.

KELEMAN, S. Mito e Corpo. São Paulo: Summus, 2001.

OVÍDIO. Metamorfoses. Trad. Vera Lucia L. Magyar. São Paulo: Madras, 2003.

PAREDES, E. W. P. Hermenêutica das bases ancestrais da educação e seus desdobramentos simbólicos nos movimentos indígenas no Equador. São Paulo: USP, 2011. (Originalmente apresentada como Tese de Doutorado na Faculdade de Educação da Universidade São Paulo, 2011).

Recebido: 29/11/2016

Received: 11/29/2016

Aprovado: 05/03/2018 Approved: 03/05/2018 